\title{
Performance characteristics of a quantitative PCR assay on repository stool specimens and smeared filter-paper cards
}

\author{
Michele D. Tisdale ${ }^{1,2,3,8^{*}} \mathbb{E}$, Indrani Mitra ${ }^{1,3}$, Andrea J. McCoy ${ }^{4}$, Mark P. Simons ${ }^{4}$, Nathanael D. Reynolds ${ }^{4}$, \\ Brett E. Swierczewski ${ }^{5}$, Jie Liu ${ }^{6}$, Eric R. Houpt ${ }^{6}$, Jamie A. Fraser ${ }^{1,3}$, Mark S. Riddle ${ }^{7}$, David R. Tribble \\ and Tahaniyat Lalani ${ }^{1,2,3}$
}

\begin{abstract}
Objective: Stool repositories are a valuable resource for retrospective analyses including quantitative PCR assays to distinguish between asymptomatic shedding and clinical disease. The suitability of archival specimens for this purpose is unclear and requires assessment. We conducted a pilot study to evaluate pathogen detection by TaqMan Array Card (TAC) in travelers' diarrhea (TD) stool specimens stored for 1-13 years, as well as the impact of transporting specimens on Whatman FTA Elute cards (FTA Cards) on detection.

Results: The positive percent agreement (PPA) for TAC on stool vs. microbiologic testing was lower than our a priori PPA estimate of $80 \%$ for most pathogens: Shigella spp. (100\% [95\%Cl 69-100\%]), enterotoxigenic E coli (ETEC) (63\% [95\%Cl 49-75\%]), Campylobacter spp. (66\% [95\%Cl 43-85\%]) and Norovirus (37\% [95\%Cl 16-61\%]). Use of the FTA card resulted in a further reduction of PPA. Our findings suggest that archival specimens may lead to insensitive detection on quantitative PCR assays due to degradation of nucleic acid with prolonged storage, although our limited sample size precluded us from evaluating the impact of storage duration on nucleic acid yield. Additional studies are needed to understand the impact of storage duration on quantitative PCR data.
\end{abstract}

Keywords: Diarrhea, Polymerase chain reaction, Travel, Archives

\section{Introduction}

Polymerase Chain Reaction (PCR) assays have significantly improved the detection of travelers' diarrhea (TD) pathogens but interpreting results is often challenging due to asymptomatic shedding and multi-pathogen detection [1-3]. Studies evaluating the performance characteristics of PCR assays have largely been conducted in clinic or hospital settings using diarrheal samples tested within days of collection $[4,5]$. This sampling method is limited by the infrequency of TD pathogens

\footnotetext{
*Correspondence: Michele.d.tisdale.ctr@mail.mil

${ }^{8}$ Infectious Disease \& Travel Clinic, Building 3, 1st Floor, Naval Medical

Center Portsmouth, Portsmouth, VA 23708, USA

Full list of author information is available at the end of the article
}

such as enterotoxigenic Escherichia coli, Shigella spp. and Campylobacter spp. and the lack of appropriately matched control specimens (e.g. asymptomatic travelers) for attribution of TD to detected pathogens. PCR data from longitudinal pediatric cohorts in developing countries cannot be readily extrapolated to adult TD populations due to differences in the host and environment that impact pathogen load and multi-pathogen detection in stool samples [6].

Biorepositories of clinically characterized diarrheal and non-diarrheal specimens provide an alternative resource to investigate clinical interpretation of PCR assay results. Biorepository specimens could be used to determine the odds of TD associated with detection of specific pathogens, and potentially refine estimates using quantification

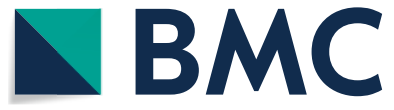

(c) The Author(s) 2020. This article is licensed under a Creative Commons Attribution 4.0 International License, which permits use, sharing, adaptation, distribution and reproduction in any medium or format, as long as you give appropriate credit to the original author(s) and the source, provide a link to the Creative Commons licence, and indicate if changes were made. The images or other third party material in this article are included in the article's Creative Commons licence, unless indicated otherwise in a credit line to the material. If material is not included in the article's Creative Commons licence and your intended use is not permitted by statutory regulation or exceeds the permitted use, you will need to obtain permission directly from the copyright holder. To view a copy of this licence, visit http://creativecommons.org/licenses/by/4.0/. The Creative Commons Public Domain Dedication waiver (http://creativecommons.org/publicdomain/zero/1.0/) applies to the data made available in this article, unless otherwise stated in a credit line to the data. 
cycle (Cq) thresholds for pathogens detected in cases and controls. The suitability of archival specimens for DNA/ RNA amplification and impact on assay performance is unclear, due to potential degradation. There are also logistical challenges in transporting frozen fecal specimens from global biorepositories to a single testing site while maintaining the cold-chain, which can be cost-prohibitive. The Whatman FTA Elute Card ${ }^{\circledR}$ (FTA card, GE Healthcare Life Sciences, WB120411, Marlborough, MA, USA) is an attractive alternative to conventional storage and shipment methods, as they can be shipped by regular mail at room temperature. The impact of using FTA Cards for sample storage and transportation on PCR sensitivity has not been evaluated.

\section{Main text \\ Methods}

We conducted a pilot study using a customized TD TaqMan Array Card (TAC, Life Technologies, Carlsbad, CA, USA) to assess the feasibility of using archived diarrheal specimens, of varying time periods, focusing on four TD pathogens: enterotoxigenic $E$ coli (ETEC), Shigella spp., Campylobacter spp., and Norovirus. Two United States Department of Defense (DoD) fecal repositories of adult TD cases, tested using standard microbiologic methods at the time of sample collection, were utilized for the study $[7,8]$ :

- Naval Medical Research Unit-6, Lima, Peru (NAMRU-6): Archived samples collected between 2003 and 2010 were tested for Campylobacter and Shigella by stool culture, Norovirus by PCR, and ETEC by stool culture followed by PCR of 5 colonies. Samples collected in 2013 were tested for all 4 pathogens by PCR.

- Armed Forces Research Institute of Medical Sciences (AFRIMS), Bangkok, Thailand: Archived samples collected between 2013 and 2016 were tested by PCR (Luminex xTAG Gastrointestinal Pathogen Panel), stool culture and ELISA. A positive result from any test was considered positive for the pathogen.

We evaluated the Positive Percent Agreement (PPA) and Negative Percent Agreement (NPA) of TAC for detecting TD pathogens in archived fecal specimens, using results from previous microbiologic testing as the 'benchmark.' We also evaluated the impact of storage duration and use of FTA cards on TAC sensitivity. Prior reports estimated a sensitivity and specificity of $>90 \%$ of PCR assays albeit with shorter sample storage duration $(4,5)$. We estimated a PPA and NPA of $80 \%$ for the TAC assay and a precision of $10 \%$. Approximately 65 positive stool specimens per pathogen for ETEC, Shigella spp., Campylobacter spp., and Norovirus and 30 samples negative for all pathogens, were requested. Descriptive statistics were used to evaluate the PPA, NPA and 95\% confidence intervals (CI) and the Mann-Whitney $U$ was performed for continuous variables. The study was approved by the Institutional Review Boards (IRB) of the Uniformed Services University and reviewed by the research office at NAMRU-6 and Walter Reed Army Institute of Research/Armed Forces Research Institute, Thailand (AFRIMS).

All stool samples were thawed, vortexed and approximately $20 \mu \mathrm{L}$ smeared onto an FTA card and shipped at room temperature to Naval Medical Center Portsmouth (NMCP) for testing. Due to logistic and regulatory constraints a limited number of stool specimens were shipped from NAMRU-6 and only smeared FTA Cards were shipped from AFRIMS. 109 out of 261 (41.7\%) stool samples were aliquoted and shipped at $-20{ }^{\circ} \mathrm{C}$ for testing (Fig. 1). Laboratory personnel performing TAC testing were blinded to the results from previous testing. FTA Cards from NAMRU-6 were received as a single batch two years before stool samples due to delays in getting required approvals for shipment (Fig. 1). FTA cards were stored at room temperature $\left(20-24{ }^{\circ} \mathrm{C}\right)$ until stool samples were received. Stool samples were tested within a month of receipt from NAMRU-6 and to reduce between run variability, we included corresponding FTA Card and stool samples in the same PCR run. FTA Cards from AFRIMS were batch shipped to NMCP and tested within a month of receipt. Extraction and TAC testing was performed as previously described [9].

\section{Results}

Two hundred and sixty-one samples for targeted pathogens were available: ETEC $(n=70)$, Shigella $(n=62)$, Campylobacter $(n=59)$, Norovirus $(n=27)$. Four samples were positive for more than 1 pathogen and 47 samples were negative for all targeted pathogens.

The PPA for TAC on stool vs. benchmark was lower than our a priori PPA estimate of $80 \%$ across all pathogens except Shigella (Table 1). For example, the ETEC TAC PPA was $62.7 \%$ [95\%CI 49.2-75.0]. The ETEC TAC PPA was numerically lower in samples stored for $\leq 3$ years vs. those stored for 5-13 years $(69.2 \%$ [95\%CI 38.6-90.9] vs. 60.8\% [95\%CI 45.4-74.9]) although this was confounded by the use of direct-on-stool PCR as benchmark for samples stored for $\leq 3$ years and culture followed by PCR of colonies in samples stored for 5-13 years. The low PPA contrasts with data published by Liu et al. reporting 100\% [95\%CI 69.2-100.0] TAC PPA on 10 ETEC positive samples stored for $2-4$ years, using stool culture and PCR of colonies as the benchmark [10]. Of note, the $95 \% \mathrm{CI}$ in both studies is large due to the 


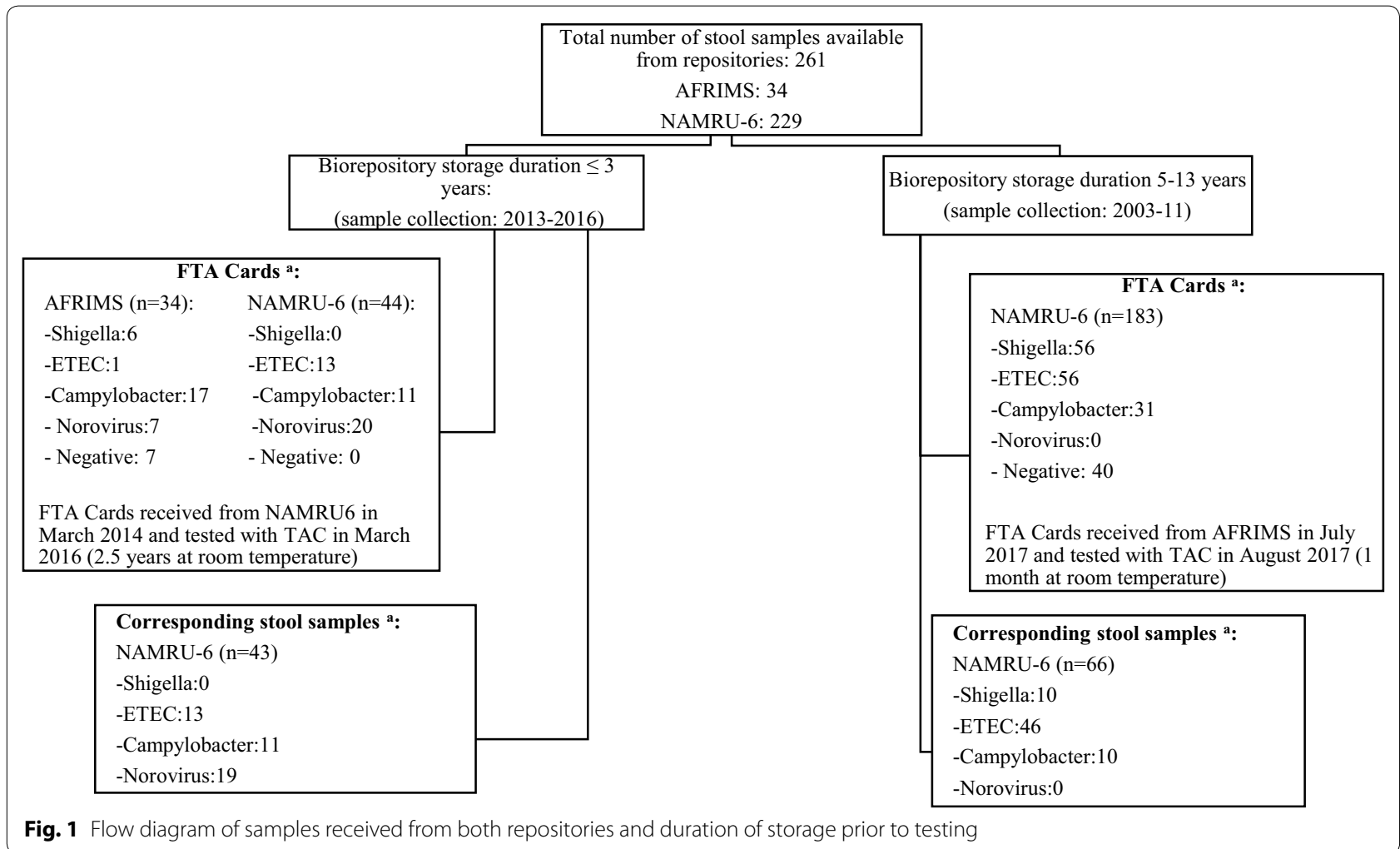

small sample size. Similarly, TAC PPA for 21 Campylobacter positive stool samples (66.6\% [95\%CI 43.0-85.4]) was lower than the published estimate of $97.1 \%$ [95\%CI 85.1-99.9] [4]. Use of the FTA card resulted in a further reduction of PPA across bacterial targets (Table 1). A large proportion of samples with discordant results (i.e. TAC positive stool and TAC negative FTA card) had high stool $\mathrm{Cq}$ values (between 30 and 35). Of the 13 paired samples with discordant ETEC detection, 11 had stool Cq values between 30 and 35 . A similar proportion of discordant samples was observed for Campylobacter (15/17) but not for Shigella (4/9) or Norovirus (6/18). TAC PPA for Norovirus was significantly lower than bacterial targets in stool (36.8\% [95\%CI 16.2-61.6]) and FTA Card (51.8\% [95\%CI 32.0-71.3]). TAC detected an additional 77 and 50 samples positive for targeted pathogens on stool and FTA card respectively, compared to benchmark testing. A decrease in PPA with increasing duration of storage (i.e. $\leq 3$ years and $5-13$ years) was noted for ETEC and Campylobacter positive FTA Cards, although the analysis was limited by small sample size and wide confidence intervals of PPA estimates between strata of storage duration and could not be assessed for Shigella or Norovirus (Table 1). To evaluate whether the sensitivity loss in samples with prolonged storage duration was due to PCR inhibition, we compared the difference in extrinsic control Cq between the sample and corresponding extraction blank. A higher Cq value in stool or FTA card compared to the corresponding extraction blank indicated a loss in PCR signal due to inhibition. A Cq difference of 3.3 was considered equivalent to a $1-\log$ loss in PCR signal due to inhibition. The proportion of samples that met this criterion were similar in the two storage duration strata, suggesting that loss of sensitivity was not due to lower extraction/amplification efficiency or inhibition.

Next, we compared Cq values of TAC on stool and FTA cards for 109 paired samples stratified by pathogen and results from benchmark testing (Fig. 2). We hypothesized that $\mathrm{Cq}$ values would be lower in FTA card and stool samples that were positive on benchmark testing vs. negative samples. A wide range of $\mathrm{Cq}$ values were observed across all pathogens and a significant difference in the median Cq value between benchmark positive and negative samples was only observed in FTA Cards positive for Campylobacter $(\mathrm{p}=0.036)$ and Shigella $(\mathrm{p}=0.046)$.

\section{Discussion}

We tested archived stool specimens using TAC to determine the feasibility of using these specimens for clinical validation of TAC. The results show a lower than expected PPA of TAC on archival samples and 
Table 1 Summary of performance characteristics of PCR assay tested in this study and reported literature

\begin{tabular}{|c|c|c|c|c|}
\hline \multicolumn{5}{|c|}{ TAC on stool vs. benchmark } \\
\hline \multirow[t]{2}{*}{ Pathogen } & \multicolumn{2}{|c|}{$\begin{array}{l}\text { This study-total number of stool samples tested } \\
\text { by TAC }=109\end{array}$} & \multicolumn{2}{|l|}{ Reported literature } \\
\hline & $\begin{array}{l}\text { Median storage duration } \\
\text { (IQR) and no. of samples: }\end{array}$ & PPA and NPA & Study design & PPA and NPA \\
\hline $\begin{array}{l}\text { ETEC } \\
\text { LT (labile toxin) } \\
\text { ST (stable toxin) }\end{array}$ & $\begin{array}{l}\text { No of samples: } 59 \\
11.5 \text { (7.2- } 12.0) \text { years } \\
\leq 3 \text { years: } 13 \text { samples } \\
5-13 \text { years: } 46 \text { samples }\end{array}$ & $\begin{array}{l}\text { PPA:62.7 (49.2-75.0) } \\
\text { NPA:70.0 (55.4-82.1) } \\
\text { Stratified by duration: } \\
\text { < } 3 \text { years: PPA: 69.2 (38.6-90.9) } \\
\text { NPA: } 66.7 \text { (47.2-82.7) } \\
\text { 5-13 years: PPA: } 60.8 \text { (45.4-74.9) } \\
\text { NPA: } 75.0 \text { (50.9-91.3) }\end{array}$ & $\begin{array}{l}\text { Sample size: } 109 \text { (10 ETEC positive) } \\
\text { Comparator: Culture + PCR of } 5 \\
\text { colonies } \\
\text { PCR platform: TAC } \\
\text { Storage duration: } 2-4 \text { years (10) }\end{array}$ & $\begin{array}{l}\text { PPA: } 100.0 \text { (69.2-100.0) } \\
\text { NPA (ETEC LT): } 55.0(41.6-67.9) \\
\text { NPA (ETEC ST): } 69.7(57.1-80.4)\end{array}$ \\
\hline Campylobacter & $\begin{array}{l}\text { No of samples: } 21 \\
2.6 \text { ( } 2.6-11.4) \text { years } \\
\leq 3 \text { years: } 11 \\
\text { 5-13 years: } 10\end{array}$ & $\begin{array}{l}\text { PPA:66.6 (43.0-85.4) } \\
\text { NPA:69.3 (58.6-78.7) } \\
\text { Stratified by duration: } \\
\text { <3 years: PPA: 63.6 (30.8-89.0) } \\
\text { NPA: } 68.8 \text { (50.0-83.8) } \\
\text { 5-13 years: PPA: 70.0 (34.8-93.3) } \\
\text { NPA: } 69.6 \text { (56.0-81.2) }\end{array}$ & $\begin{array}{l}\text { Sample size: } 1557 \text { (35 Campylobacter } \\
\text { positive) } \\
\text { Comparator: Culture } \\
\text { PCR platform: BioFire FilmArray Gl } \\
\text { panel } \\
\text { Storage duration: days-weeks (4) }\end{array}$ & $\begin{array}{l}\text { PPA:97.1 (85.1-99.9) } \\
\text { NPA:98.4 (97.7-99.0) }\end{array}$ \\
\hline Shigella/EIEC & $\begin{array}{l}\text { No of samples: } 10 \\
7.6(6.7-10) \text { years } \\
5-13 \text { years: } 10\end{array}$ & $\begin{array}{l}\text { PPA:100.0 (69.2-100.0) } \\
\text { NPA:82.8 (74.0-89.6) }\end{array}$ & $\begin{array}{l}\text { Sample size: } 1557 \text { (49 Shigella/EIEC } \\
\text { positive) } \\
\text { Comparator: Culture (PCR for EIEC) } \\
\text { PCR platform: BioFire FilmArray Gl } \\
\text { panel } \\
\text { Storage duration: days-weeks (4) }\end{array}$ & $\begin{array}{l}\text { PPA:95.9 (86.0-99.5) } \\
\text { NPA:98.5 (99.5-130.0) }\end{array}$ \\
\hline Norovirus & $\begin{array}{l}\text { No of samples: } 19 \\
2.6(2.6-2.6) \text { years } \\
\leq 3 \text { years: } 19\end{array}$ & $\begin{array}{l}\text { PPA:36.8 (16.2-61.6) } \\
\text { NPA:80.0 (70.2-87.6) }\end{array}$ & $\begin{array}{l}\text { Sample size: } 1557 \text { ( } 55 \text { Norovirus } \\
\text { positive) } \\
\text { Comparator: RT-PCR } \\
\text { PCR platform: BioFire FilmArray Gl } \\
\text { panel } \\
\text { Storage duration: days-weeks (4) }\end{array}$ & $\begin{array}{l}\text { PPA:94.5 (84.9-98.9) } \\
\text { NPA:98.8 (98.1-99.3) }\end{array}$ \\
\hline
\end{tabular}

\begin{tabular}{|c|c|c|c|c|c|}
\hline \multicolumn{6}{|c|}{ TAC on FTA card vs. standard microbiology (benchmark) This study - total number of FTA cards tested by TAC $=261$} \\
\hline Pathogen & \multicolumn{2}{|c|}{$\begin{array}{l}\text { Median storage duration (IQR) and no. } \\
\text { of samples: }\end{array}$} & \multicolumn{2}{|c|}{ PPA and NPA } & Stratified by duration: \\
\hline ETEC & \multicolumn{2}{|c|}{$\begin{array}{l}\text { No of samples: } 70 ; 10.5(6.9-12.0) \text { years } \\
\leq 3 \text { years: } 14 \\
5-13 \text { years: } 56\end{array}$} & \multicolumn{2}{|c|}{$\begin{array}{l}\text { PPA:55.7 (43.3-67.6) } \\
\text { NPA:85.3 (80.0-90.0) }\end{array}$} & $\begin{array}{l}\leq 3 \text { years: PPA: } 57.1(28.8-82.3) \\
\text { NPA: } 86.0 \text { (75.0-93.3) } \\
\text { 5-13 years: PPA: } 55.4(41.4-68.6) \\
\text { NPA: } 85.0 \text { (77.6-90.8) }\end{array}$ \\
\hline Campylobacter & \multicolumn{2}{|c|}{$\begin{array}{l}\text { No of samples: } 59 ; 10.4(2.6-11.8) \text { years } \\
\leq 3 \text { years: } 28 \\
5-13 \text { years: } 31\end{array}$} & \multicolumn{2}{|c|}{$\begin{array}{l}\text { PPA:62.7 (49.2-75.0) } \\
\text { NPA:82.2 (76.2-87.2) }\end{array}$} & $\begin{array}{l}\leq 3 \text { years: PPA:71.4 (51.3-86.8) } \\
\text { NPA: } 84.0 \text { (70.8-92.8) } \\
\text { 5-13 years: PPA: } 54.8(36.0-72.6) \\
\text { NPA: } 81.6 \text { (74.4-87.4) }\end{array}$ \\
\hline Shigella & \multicolumn{2}{|c|}{$\begin{array}{l}\text { No of samples: } 62 ; 6.0(2.5-7.6) \text { years } \\
\leq 3 \text { years: } 6 \\
5-13 \text { years: } 56\end{array}$} & \multicolumn{2}{|c|}{$\begin{array}{l}\text { PPA:88.7 (78.1-95.3) } \\
\text { NPA:86.4 (81.0-91.0) }\end{array}$} & $\begin{array}{l}\leq 3 \text { years: PPA: } 16.6(1.0-64.1) \\
\text { NPA: } 94.4 \text { (86.4-98.4) } \\
\text { 5-13 years: PPA: } 96.4(87.6-99.6) \\
\text { NPA: } 81.8 \text { (74.0-88.2) }\end{array}$ \\
\hline Norovirus & \multicolumn{2}{|c|}{ No. of samples: $27 ; 2.6(2.6-2.6)$ years } & \multicolumn{2}{|c|}{$\begin{array}{l}\text { PPA:51.8 (32.0-71.3) } \\
\text { NPA:97.8 (95.0-99.3) }\end{array}$} & N/A (all samples stored $\leq 3$ years) \\
\hline \multicolumn{6}{|c|}{ TAC on FTA card vs. TAC on stool (benchmark) } \\
\hline \multirow[t]{2}{*}{ Pathogen } & \multicolumn{3}{|c|}{$\begin{array}{l}\text { This study-total number of paired FTA cards and stool samples } \\
\text { tested by TAC }=109\end{array}$} & \multicolumn{2}{|l|}{ Reported Literature } \\
\hline & $\begin{array}{l}\text { Median storage duration (IQR) } \\
\text { and no. of samples: }\end{array}$ & \multicolumn{2}{|l|}{ PPA and NPA } & Study Design & PPA and NPA \\
\hline ETEC & $\begin{array}{l}\text { No. of paired samples: } 52 ; \\
\text { median duration of FTA card stor- } \\
\text { age: } 8.8(2.6-11.8) \text { years } \\
\leq 3 \text { years: } 19 \\
5-13 \text { years: } 33\end{array}$ & \multicolumn{2}{|c|}{$\begin{array}{l}\text { PPA: } 75.0 \text { (63.2-86.8) } \\
\text { NPA: } 91.2 \text { (83.8-98.6) } \\
\text { Stratified by duration: } \\
\leq 3 \text { years: PPA: } 73.6 \text { (48.8-90.8) } \\
\text { NPA: } 91.6 \text { (73.0-98.9) } \\
\text { 5-10 years: PPA: } 75.8(57.7-88.9) \\
\text { NPA: } 90.9 \text { (75.6-98.0) }\end{array}$} & $\begin{array}{l}\text { Total sample size: } 187 \\
\text { ETEC positive TAC on stool: } 85 \\
\text { Storage duration: } 2 \text { years ( } 9 \text { ) }\end{array}$ & $\begin{array}{l}\text { PPA:90.6 (82.2-96.0) } \\
\text { NPA:97.6 (93.3-99.5)(3) }\end{array}$ \\
\hline
\end{tabular}


Table 1 (continued)

\begin{tabular}{|c|c|c|c|c|}
\hline \multirow[t]{2}{*}{ Pathogen } & \multicolumn{2}{|c|}{$\begin{array}{l}\text { This study-total number of paired FTA cards and stool samples } \\
\text { tested by TAC }=109\end{array}$} & \multicolumn{2}{|l|}{ Reported Literature } \\
\hline & $\begin{array}{l}\text { Median storage duration (IQR) } \\
\text { and no. of samples: }\end{array}$ & PPA and NPA & Study Design & PPA and NPA \\
\hline Campylobacter & $\begin{array}{l}\text { No. of paired samples: } 41 \text {; median } \\
\text { storage duration: } 7.0(2.6-11.8) \\
\text { years } \\
\leq 3 \text { years: } 17 \\
5-10 \text { years: } 24\end{array}$ & 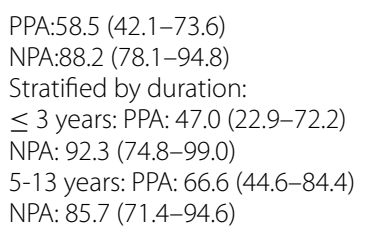 & $\begin{array}{l}\text { Total sample size: } 187 \\
\text { Campylobacter positive TAC on } \\
\text { stool: } 11 \\
\text { Storage duration: } 2 \text { years (9) }\end{array}$ & $\begin{array}{l}\text { PPA:90.9 (58.7-99.8) } \\
\text { NPA:100.0 (98.0-100.0)(3) }\end{array}$ \\
\hline Shigella & $\begin{array}{l}\text { Shigella positive TAC on stool: } 27 \\
\text { median storage duration: } 7.7 \\
(6.0-11.3) \text { years } \\
\leq 3 \text { years: } 5 \\
5-10 \text { years: } 22\end{array}$ & $\begin{array}{l}\text { PPA: } 66.6(46.0-83.4) \\
\text { NPA: } 92.6 \text { (84.8-97.2) } \\
\text { Stratified by duration: } \\
\leq 3 \text { years: PPA: } 40.0(5.2-85.3) \\
\text { NPA: } 94.7 \text { (82.2-99.4) } \\
\text { 5-13 years: PPA: } 72.7(49.8-89.2) \\
\text { NPA: } 90.9 \text { (78.3-97.4) }\end{array}$ & $\begin{array}{l}\text { Total sample size: } 187 \\
\text { Shigella positive TAC on stool: } 18 \\
\text { Storage duration: } 2 \text { years (9) }\end{array}$ & $\begin{array}{l}\text { PPA:88.9 (65.2-98.6) } \\
\text { NPA:99.4 (96.8-99.9)(3) }\end{array}$ \\
\hline Norovirus & $\begin{array}{l}\text { No of samples:19; median duration } \\
\text { of FTA card storage: } 2.6 \text { (2.6-2.6) } \\
\text { years }\end{array}$ & $\begin{array}{l}\text { PPA:28.0 (12.0-49.4) } \\
\text { NPA:92.8 (85.1-97.3) } \\
\text { Stratified by duration: } \\
\text { S3 years: PPA: } 36.4(10.9-69.2) \\
\text { NPA: } 81.2(636-92.8) \\
\text { 5-13 years: PPA: } 21.4(4.6-50.8) \\
\text { NPA: } 100.0(93.2-100.0)\end{array}$ & $\begin{array}{l}\text { Total sample size: } 187 \\
\text { Norovirus positive TAC on stool: } 24 \\
\text { Storage duration: } 2 \text { years (9) }\end{array}$ & $\begin{array}{l}\text { PPA:38.0 (18.8-60.0) } \\
\text { NPA:100.0 (98.9-100.0)(3) }\end{array}$ \\
\hline
\end{tabular}

significant variability in PPA estimates by pathogen when compared to previously published estimates [4, 5]. This is partly explained by the small sample size resulting in wide confidence intervals, an important limitation in our study as well as prior reports [7, 9]. The results suggest that using TAC on archival samples stored for several years may lower sensitivity and underestimate pathogen burden. Published reports, largely in the realm of microbiome research, focus on relatively short storage durations of days to months [11, 12]. Cannon et al. reported a $2.7 \%$ [95\% CI 2.1-3.5\%] decline in the percentage of samples positive on re-testing for norovirus by RT-PCR, with each additional year of storage at $4{ }^{\circ} \mathrm{C}$ and $\mathrm{a}-1 \log$ loss of viral RNA titer with each 7-year period of sample storage at $4^{\circ} \mathrm{C}$ [13]. We were only able to detect 7 of 19 Norovirus positive stool samples (PPA: 36.8\% [16.2-61.6]) despite a short duration of storage $(2.6$ years $)$ at $-80^{\circ} \mathrm{C}$. It is possible that the freeze-thaw cycles associated with transportation of specimens to the testing lab impacted viral recovery. Stool samples underwent two freeze thaw cycles since shipment of stool and FTA Cards could not occur simultaneously. Bacterial targets had higher TAC PPAs (approximately 65\% for ETEC and Campylobacter) with Shigella/EIEC being the highest (10 of 10 samples positive by culture) despite a median storage duration of 7.6 years. The large variance in PPA estimates for bacterial targets and additional positives detected by TAC on FTA cards suggest that sampling error may contribute to an underestimation of the PPA, since pathogens may not be homogenously distributed in stool. Homogenization of stool samples prior to storage and the use of multiple samples from a specific time-point may reduce the variance due to sampling error [14]. In addition, careful documentation of processing, storage and sampling methods and an understanding of their impact on quantitative PCR data is needed to appropriately adjust detection estimates using archival samples.

We also evaluated smeared FTA Cards for storage and transportation of archival samples. Unfortunately, delays in receiving the stool specimens resulted in FTA Cards being stored for 2-3 years at room temperature prior to extraction and testing and negatively impacted PPA estimates for bacterial targets especially at higher stool Cqs. The PPA of TAC on FTA Cards across bacterial targets was lower than estimates from a post hoc analysis using fresh stool samples smeared on to FTA Cards and stored for approximately 2 years prior to extraction and testing [9]. This finding suggests that using archival samples that are freeze-thawed may negatively impact TAC performance on smeared FTA Cards compared to fresh stool. Additional studies are needed to evaluate strategies for increasing PCR yield from smeared FTA card such as 


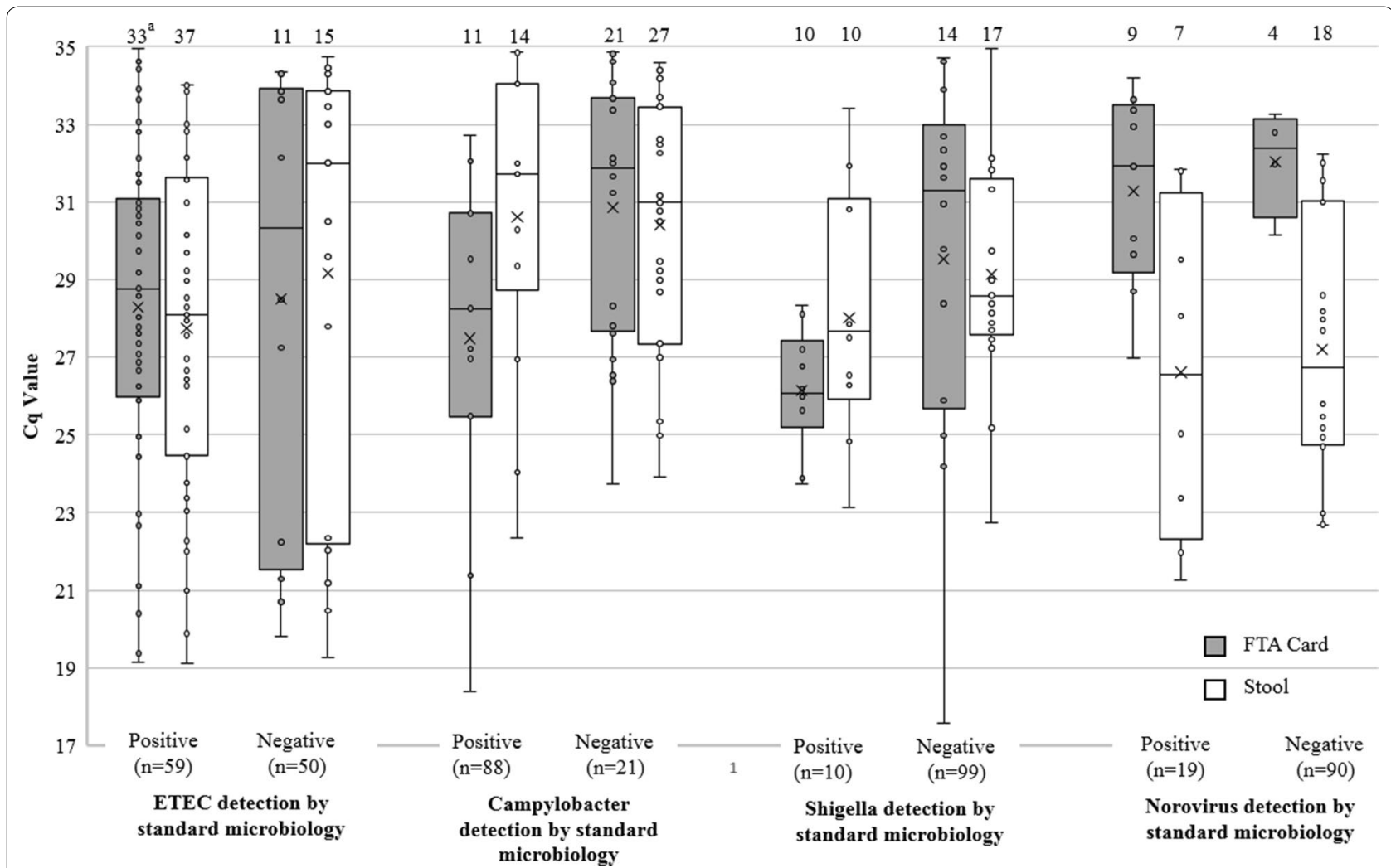

Fig. 2 FTA card and stool samples positive vs. samples negative on microbiologic testing $(n=109)$. ETEC detection by TAC includes multiple targets: LT, STh and STp. Norovirus detection by TAC on FTA cards and stool includes the Norovirus Gl or Norovirus Gll target. Shigella and Campylobacter detection was based on a single target. Significant difference in median $\mathrm{Cq}$ values observed for the following by pairwise comparison:

Campylobacter: Benchmark (+)/FTA Card(+) vs. Benchmark(-)/FTAcard(+) p =0.036. Shigella/ElEC: Benchmark (+)/FTA Card(+) vs. Benchmark $(-) /$ FTAcard $(+) p=0.046$. Norovirus: Benchmark $(-) /$ Stool $(+) N=18$ Benchmark (-)/FTAcard $(+) p=0.003$. Benchmark $(+) / S t o o l(+) N=7$ Benchmark $(+) /$ FTAcard $(+) p=0.033$. The correlation between corresponding stool and FTA card targets was poor $\left(r^{2}:\right.$ ETEC 0.37, Campylobacter: 0.27, Shigella 0.40 and Norovirus $0.07 ; p<0.01$ for all)

reducing storage duration of FTA Cards, refrigeration or adding preservatives (e.g. RNAlater [Invitrogen, Carlsbad, CA]).

Our pilot study adds important insights into the use of repository samples to validate quantitative PCR assays. TAC sensitivity on archival specimens may be lower than previous estimates using specimens with a shorter duration of storage. The study also highlights the importance of developing standard operating procedures at the inception of studies to optimize processing and preservation of fecal samples and enhance the comparability and reproducibility of data $[15,16]$. Future efforts should focus on adequately powered studies of TD stool archival specimens in order to understand the impact of storage duration on quantitative PCR data.

\section{Limitations}

An important limitation of our study was the small sample size of bacterial targets. We could not evaluate the loss of PCR signal with increasing storage duration since
TAC testing of stool samples and FTA cards occurred at a single time-point and not longitudinally at pre-specified time intervals. Microbiologic testing performed at the time of collection (i.e. benchmark) varied by site and time period, confounding the association between storage duration and TAC sensitivity. Unknown freeze-thaw cycles in archived specimens could also impact TAC performance on smeared FTA Cards compared to fresh stool.

\section{Abbreviations}

TAC: TaqMan Array Card; TD: Travelers' Diarrhea; PPA: Positive Percent Agreement; ETEC: Enterotoxigenic E coli; PCR: Polymerase Chain Reaction; Cq: Quantification cycle; DoD: Department of Defense; NAMRU-6: Naval Medical Research Unit-6, Lima, Peru; AFRIMS: Armed Forces Research Institute of Medical Sciences; NPA: Negative Percent Agreement; IRB: Institutional Review Boards; NMCP: Naval Medical Center Portsmouth.

\section{Acknowledgements}

The authors would like the thank the study investigators and dedicated lab personnel at Naval Medical Research Unit-6 Peru and the Armed Forces Research Institute of Medical Sciences for providing repository samples. 


\section{Research disclaimer}

The contents of this publication are the sole responsibility of the author(s) and do not necessarily reflect the views, opinions, or policies of the Uniformed Services University of the Health Sciences (USUHS), The Henry M. Jackson Foundation for the Advancement of Military Medicine, Inc., the US Department of Defense (DoD), or the Departments of the Army, Navy or Air Force. Mention of trade names, commercial products, or organization does not imply endorsement by the U.S. Government. A number of the co-authors are military service members (or employees of the U.S. Government). This work was prepared as part of their official duties. Title 17 U.S.C. \$105 provides that 'Copyright protection under this title is not available for any work of the United States Government.'Title 17 U.S.C. \$101 defines a U.S. Government work as a work prepared by a military service member or employee of the U.S. Government as part of that person's official duties.

\section{Authors' contributions}

TL, MR, DT and MT participated in the concept and design of the protocol. AM MS, NR, and BS provided the archived samples. MT, JL, TL and IM performed data analysis and interpretation. All authors read and approved the final manuscript.

\section{Funding}

This study, IDCRP-076, was conducted by the Infectious Disease Clinical Research Program (IDCRP), a Department of Defense (DoD) program executed by the Uniformed Services University of the Health Sciences (USUHS) through a cooperative agreement with The Henry M. Jackson Foundation for the Advancement of Military Medicine, Inc. (HJF). This project has been funded in whole, or in part, with federal funds from the National Institute of Allergy and Infectious Diseases, National Institutes of Health, under Inter-Agency Agreement Y1-Al-5072.

\section{Availability of data and materials}

The datasets used and/or analyzed during the current study are available from the corresponding author on reasonable request.

\section{Ethics approval and consent to participate}

Research data derived from an approved Uniformed Services University of the Health Sciences IRB (IDCRP-076, USUID.2013.0001) protocol. The study utilized de-identified stool samples from individuals who consented in a previous study to the storage of their specimens for future use. The Uniformed Services University of the Health Sciences Institutional Review Board deemed the study Exempt and did not require consenting.

\section{Consent for Publication}

Not applicable.

\section{Competing interests}

None of these authors have any conflicts of interest of relevance to disclose.

\section{Author details}

${ }^{1}$ Infectious Disease Clinical Research Program, Department of Preventive Medicine and Biostatistics, Uniformed Services University of the Health Sciences, Bethesda, MD, USA. ${ }^{2}$ Naval Medical Center Portsmouth, Portsmouth, VA, USA. ${ }^{3}$ The Henry M Jackson Foundation for the Advancement of Military Medicine, Inc, Bethesda, MD, USA. ${ }^{4}$ Naval Medical Research Unit-6, Lima, Peru.

${ }^{5}$ Armed Forces Research Institute of Medical Sciences, Bangkok, Thailand. ${ }^{6}$ University of Virginia, Charlottesville, VA, USA. ${ }^{7}$ Department of Preventive Medicine and Biostatistics, Uniformed Services University of the Health Sciences, Bethesda, MD, USA. ${ }^{8}$ Infectious Disease \& Travel Clinic, Building 3, 1st Floor, Naval Medical Center Portsmouth, Portsmouth, VA 23708, USA

Received: 31 July 2020 Accepted: 14 October 2020 Published online: 30 October 2020

\section{References}

1. Zautner AE, GroB U, Emele MF, Hagen RM, Frickmann H. More pathogenicity or just more pathogens? - on the interpretation problem of multiple pathogen detections with daignostic multiplex assays. Front Microbiol. 2017:8:1210

2. Tisdale MD, Tribble DR, Telu K, Fraser JA, Connor P, Philip C, et al. A comparison of stool enteropathogen detection by semiquantitative PCR in adults with acute travelers' diarrhea before and 3 weeks after succesful antibiotic treatment. OFID. 2019. 6(5):ofz187.

3. MacFarlane-Smith LR, Ahmed S, Wilcox MH. Molecular versus culturebased testing for gastrointestinal infection. Curr Opin Gastroenterol. 2018;34:19-24.

4. Buss SN, Leber A, Chapin K, Fey PD, Bankowski MJ, Jones MK, et al. Multicenter evaluation of the BioFire FilmArray gastrointestinal panel for etiologic diagnosis of infectious gastroenteritis. J Clin Microbiol. 2015:53(3):915-25.

5. Claas EC, Burnham CA, Mazzulli T, Templeton K, Topin F. Performance of the $x T A G(R)$ gastrointestinal pathogen panel, a multiplex molecular assay for simultaneous detection of bacterial, viral, and parasitic causes of infectious gastroenteritis. J Microbiol Biotechnol. 2013;23(7):1041-5.

6. Liu J, Kabir F, Manneh J, Lertsethtakarn P, Begum S, Gratz J, et al. Development and assesment of molecular diagnostic tests for 15 enteropathogens causing childhood diarrhoea: a multicenter study. Lancet Infect Dis. 2014;14:716-24.

7. Lertsethatakarn P, Silapong S, Sakpaisal P, Serichantalergs O, Ruamsap N, Lurchachaiwong W, et al. Travelers' diarrhea in Thailand: a quantitative analysis using TaqMan Array Card. Clin Infect Dis. 2018;67(1):120-7.

8. Ballard SB, Reaves EJ, Luna CG, Silva ME, Rocha C, Heitzinger K, et al. Epidemiology and genetic characterization of noroviruses among adults in an endemic setting, Peruvian Amazon basin, 2004-2011. PLoS ONE. 2015;10(7):e0131646.

9. Lalani T, Tisdale MD, Liu J, Mitra I, Philip C, Odundo E, et al. Comparison of stool collection and storage on Whatman FTA Elute cards versus frozen stool for enteropathogen detection using the TaqMan Array Card PCR assay. PLoS ONE. 2018;13(8):e0202178.

10. Liu J, Gratz J, Amour C, Kibiki G, Becker S, Janaki L, et al. A laboratorydeveloped TaqMan Array Card for simultaneous detection of 19 enteropathogens. J Clin Microbiol. 2013;51(2):472-80.

11. Panek M, Cipcic Paljetak H, Baresic A, Peric M, Matijasic M, Lojkic I, et al. Methodology challenges in studying human gut microbiota-effects of collection, storage, DNA extraction and next generation sequencing technologies. Sci Rep. 2018;8(1):5143.

12. Shaw AG, Sim K, Powell E, Cornwell E, Cramer T, McClure ZE, et al. Latitude in sample handling and storage for infant faecal microbiota studies: the elephant in the room? Microbiome. 2016;4(1):40.

13. Cannon JL, Baker M, Barclay L, Vinje J. Impact of long-term storage of clinical samples collected from 1996 to 2017 on RT-PCR detection of norovirus. J Virol Methods. 2019;267:35-41.

14. Gorzelak MA, Gill SK, Tasnim N, Ahmadi-Vand Z, Jay M, Gibson DL. Methods for improving human gut microbiome data by reducing variability through sample processing and storage of stool. PLoS ONE. 2015;10(8):1371.

15. Sinha R, Abnet CC, White $O$, Knight $R$, Huttenhower $C$. The microbiome quality control project: baseline study design and future directions. Genome Biol. 2015;16:276.

16. Costea PI, Zeller G, Sunagawa S, Pelletier E, Alberti A, Levenez F, et al. Towards standards for human fecal sample processing in metagenomic studies. Nat Biotechnol. 2017:35:1069-76.

\section{Publisher's Note}

Springer Nature remains neutral with regard to jurisdictional claims in published maps and institutional affiliations. 